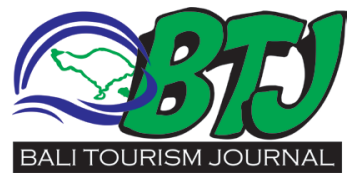

\section{To survive or perish, Nyoman and Ketut existences at stake!}

\author{
Ida Bagus Gede Karyambara Putra ${ }^{1}$
}

\title{
ABSTRACT
}

Governor of Bali, Dr. Ir. I Wayan Koster, M.M. recently instructed his regents through Governor Instruction Number 1545 of 2019 to promote Krama Bali Family Planning (KBFP); a 'four children policy' instead of National family planning program (FPP) a 'two children policy. The central government deployed FPP as an effective way to prevent population explosion in the last fifty years; which is highly crucial to ensure the society's welfare in future. In contrast, apparently, from the Governor of Bali, Wayan Koster's perspective, the program is subduing Balinese society growth, and threatening the survivability of the third and fourth child generations (Nyoman and Ketut). Through the Instruction, it is expected the Balinese family would decide to have more than two children, as the Governor's wish to protect the ancestral noble heritage. In these times, there are several things that a family should be taken into account before deciding to follow KBFP program; from the female side agreement, family's cashflow condition, and recent demographic situation of Bali that has been expanding rapidly for years. Nevertheless, the instruction is not sternly applied, since there is no sanction for the society who wish not to follow the government's suggestion. As a verdict, a Balinese family still own the power to decide independently what they may find suitable for their future.

Keyword: Governor Instruction, Krama Bali Family Planning, Program

Cite This Article: Putra, I.B.G.K. To survive or perish, Nyoman and Ketut existences at stake!. Bali Tourism Journal (BTJ)2019, 3 (1): 30-33.

${ }^{1}$ AVSEC PT. Angkasa Pura;

colekpamor9@gmail.com

\section{Editor:}

Ida Bagus Ngurah Tri Pramana
Received : 2019-07-4 Accepted : 2019-07-26 Published: $2019-08-29$

\section{BACKGROUND}

Governor of Bali, Dr. Ir. I Wayan Koster, M.M. recently instructed his regents through Governor Instruction Number 1545 of 2019 to promote Krama Bali Family Planning (KBFP); a 'four children policy' instead of National program a 'two children policy. He firstly addressed the issue in 2018 on his campaign for governor election. He argued should Balinese decide to have two children, it would be detrimental for their heritage survivability. ${ }^{1}$ Koster has been known for his political agenda to promote and strengthen Balinese customs; from promoting application of Balinese scripture, traditional clothes, festival, until significant breakthrough to reduce plastic waste. ${ }^{2}$ Beyond his brilliant programs that received full support from the community, yet KBFP sparks a blatant indifference in society. Some criticise would it be a wise move from Government to promote the policy today?

\section{THE KRAMA BALI FAMILY PLANNING PROGRAM}

In his political campaign to seize 'Bali top position', Koster proposed the central government to slightly modify the Family Planning Program (FPP) in Bali, from having two children to four children. The folk recognise four hierarchy traditional names according to the birth order of the child. There are
Wayan, Gede, or Putu which are usually used for the name of the first child. Made, Kadek, or Nengah for the name of the second child. Nyoman or Komang for the name of the third child, and Ketut for the fourth child. He suggests, should the national FPP control the number of Balinese family children, definitely two generations would be lost. We would rarely find people with the name Nyoman and Ketut, or worse, those two name might extinct from the Balinese society. ${ }^{4}$

According to Koster, the Balinese applied Catur Guru Bakti teaching. One of the points is to respect the government, including its policies. Hence, the FPP for two children is well-performed in Bali. However, their obedience apparently leads to the situation where the name owner of Nyoman or Komang and Ketut are rare. "It is our custom, and we must protect it whatever it costs" Koster said. This politician from Sembiran village revealed the number of population data in Bali from a specific time frame. Based on the number of family in Bali, averagly, they only have two children which explains why the Balinese community growth is stagnant. In addition to generation loss, the government of Bali is also prone to potential losses in financial support. Due to the number of populations would affected financial funds from the central government. ${ }^{5}$

After being elected as Governor of Bali for the period 2019 - 2024, ${ }^{7}$ the implementation of 


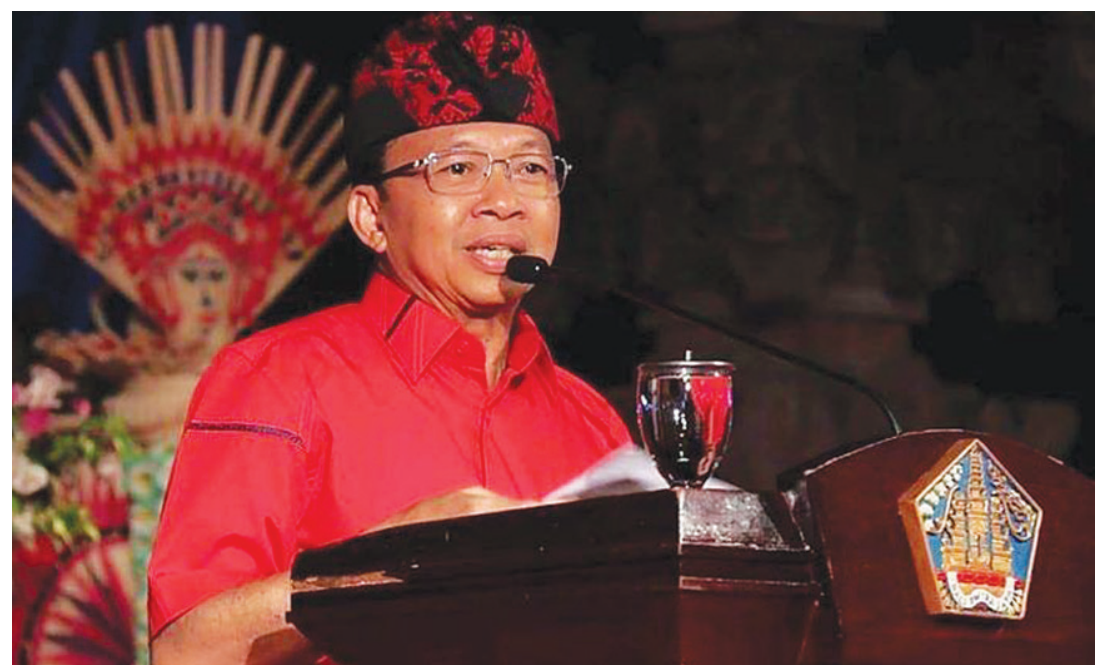

Figure 1. Governor of Bali, Dr. Ir. I Wayan Koster, M.M³

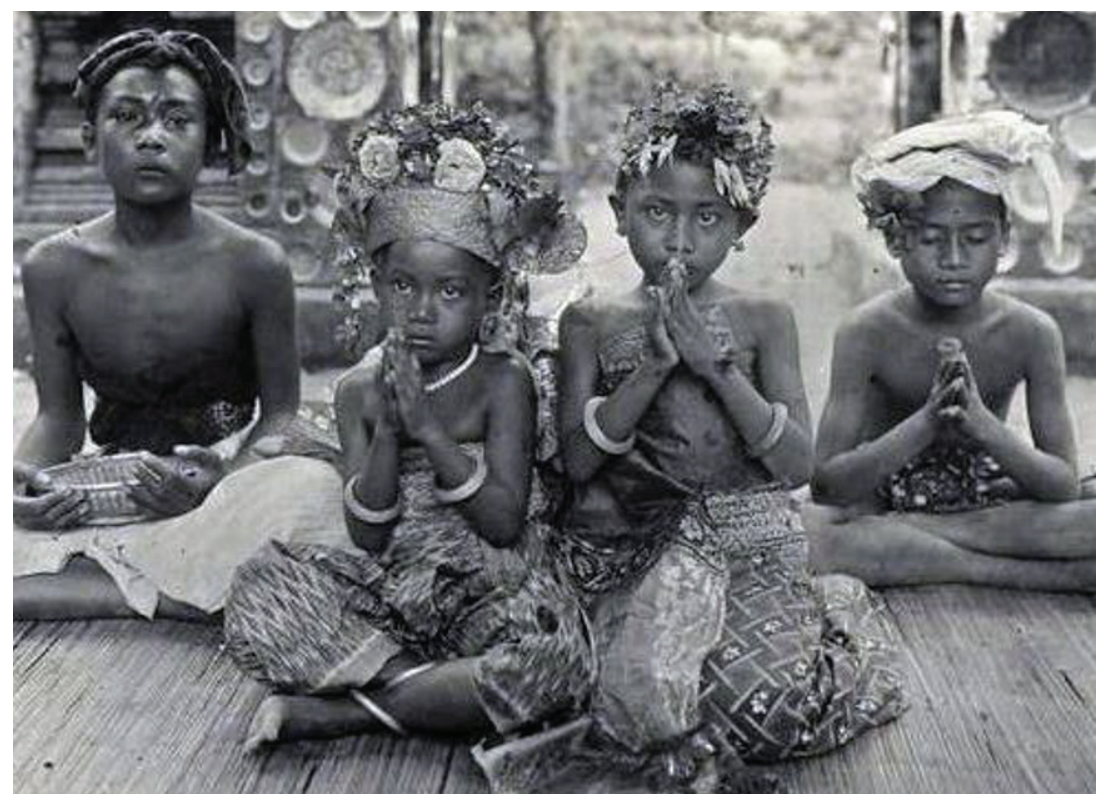

Figure 2. The folk recognise four hierarchy traditional names according to the birth order of the child. There are Wayan, Made, Nyoman and Ketut. $^{6}$

4-child family program was launched as Governor Instruction Number 1545 of 2019, concerning the Socialization of the KBFP Program. The instruction, however, does not specifically suggest the number of children to be owned by each Balinese family. The message implicitly conveyed in point number 2 which states KBFP based on local wisdom. ${ }^{8}$ In fact, the Governor's instruction is more recommendation-likely, thus to those who do not want or unable to have more than two offspring would not be subject to sanctions. Koster assures, if the community decide to implement the program, there is no need to worry about economic problems. The government through the state budget and regional budget have spent some funds to support the program. Furthermore, He also pointed out pleasant fact that Bali's average income is gradually increasing every year.

\section{THE RISE OF FAMILY PLANNING PRO- GRAM}

History of population control in Indonesia began in 1968. Yet the idea to limit the number of births in Indonesia firstly broadcasted in the 1950s. Before that time, Indonesian people, in general, still had the notion that having many children would have an impact on the economic welfare of the family in the future. Children in the future will become the backbone of the family, and by owning many of them, would undoubtedly multiply the family's fortune. However, some health practitioners were beginning to realise on the significant increase in the population. Moreover, at that time, a woman who experienced more than two deliveries have low survival rate.

Head of the Department of Maternal and Child Welfare at the Ministry of Health in Yogyakarta, Doctor Julie Sulianti Saroso, On her interview with the Kedaulatan Rakjat newspaper in 1952 as cited on tirto.id, mothers should have a courage, and willingly to limit births, due to numerous mothers as well as infant died on delivery. Prominent figures such as Mrs Marsidah Soewito, Sarwono Prawirohardjo, M. Judono, Koen S. Martiono, dr. Hurustiati Subandrio, and dr. Hanifa Wiknjosastro were assertively broadcasting the importance of birth control. However, pressure from the community and the central government at that time made this campaign carried out secretly underground.

Until October 17, 1968, after the Coordinating Minister for People's Welfare. Idham Chalid conducted meticulous researches regarding to birth control and with President Soeharto's permission, a semi-governmental institute Lembaga Keluarga Berencana Nasional or National Family Planning Institute (LKBN) was established. LKBN eventually became a non-departmental government agency named Badan Koordinasi Keluarga Berencana Nasional or the National Family Planning Coordinating Board (BKKBN) in 1970, based on Presidential Decree No. 8 of 1970. BKKBN launched a Keluarga Berencana $(\mathrm{KB})$ or Family Planning Program (FPP) program in which the community was expected to regulate childbirth by only having two children. The program's slogan is "Two children are enough, either males or females". 10

Inflation, limited employment, rapid increase on education as well as high health costs generate 


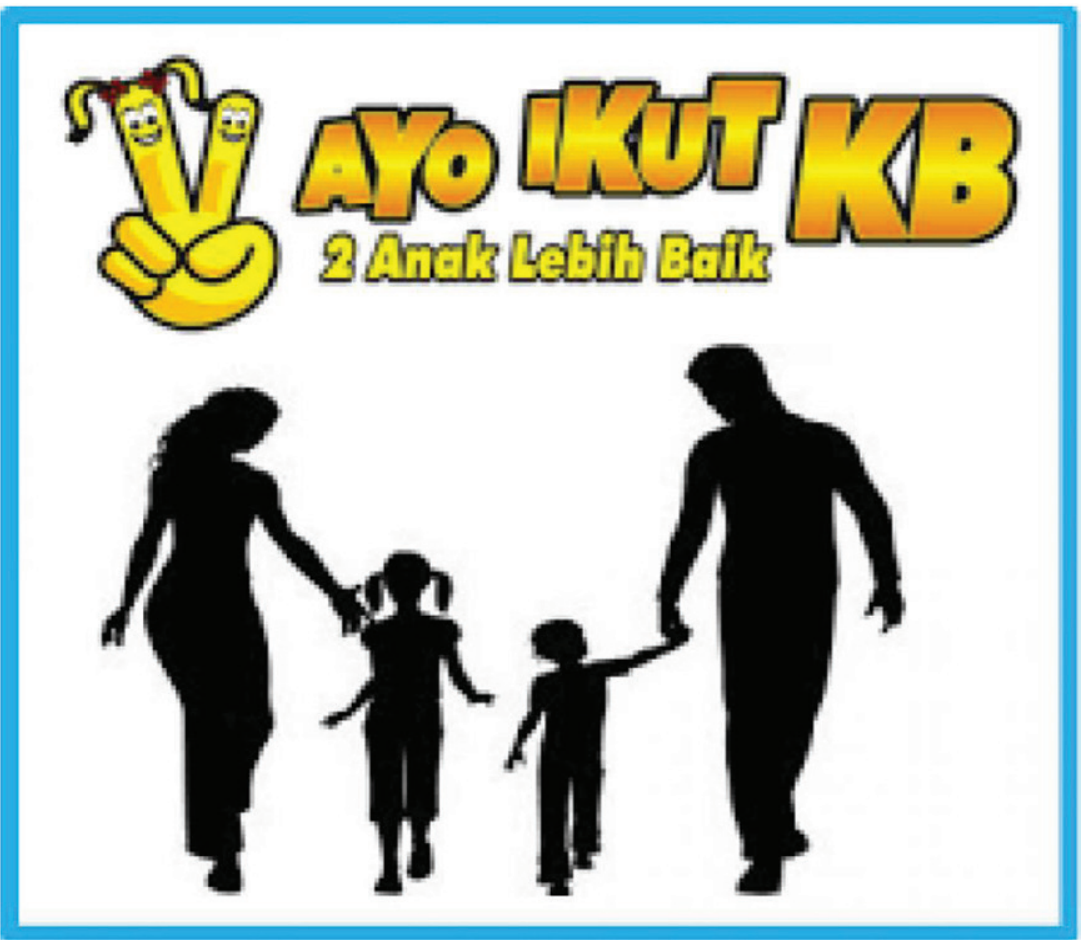

Figure 3. Keluarga Berencana (KB) or Family Planning Program (FPP) promotion banner ${ }^{9}$

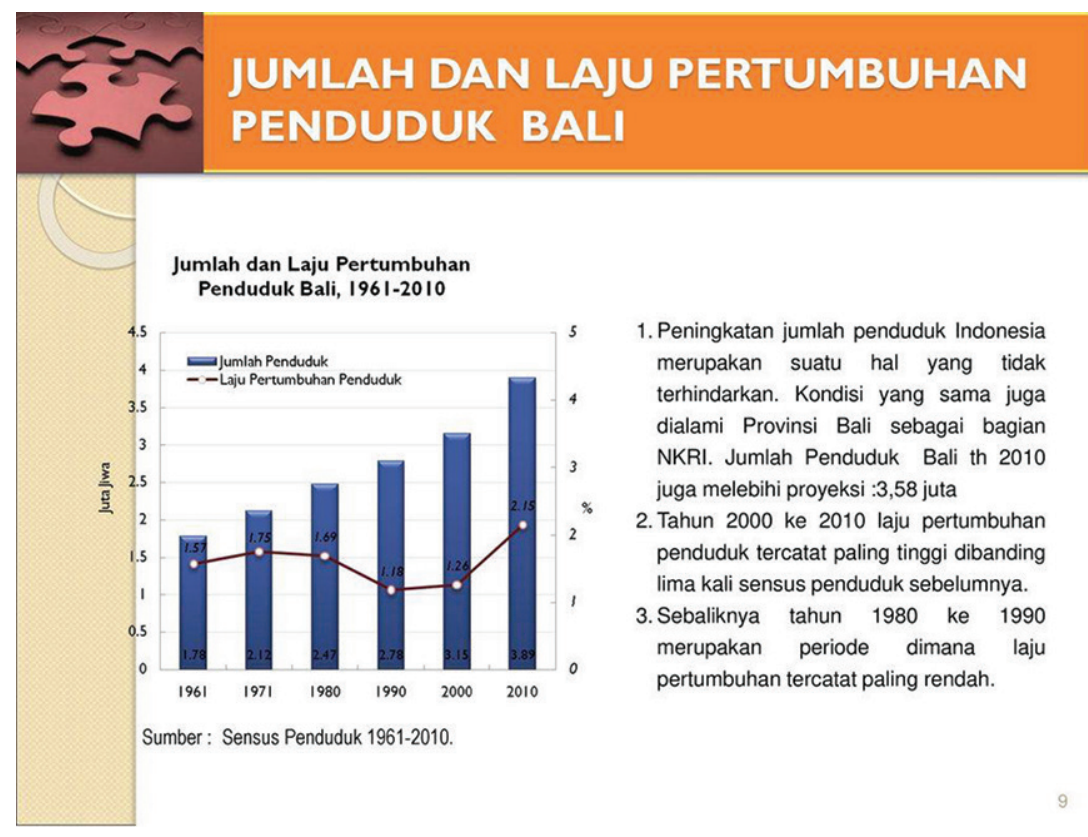

Figure 4. Presented Slide by BKKBN Provinsi Bali entitled 'KEBIJAKAN DAN STRATEGI PEMBANGUNAN KEPENDUDUKAN DAN KB TAHUN 2012 shows there are more than double in population increases from 1961 to $2019 .{ }^{12}$

significant impact on middle and lower economic class' prosperity. Especially for the lower class, they tended to neglect the quality of individual health or to ensure proper education for their children. Additionally, if a low-income economic group owned more than two children, then the problems would be inevitable; the children's health and education are not the family number one priority. It did not take a while to FPP showed its relevance after firstly introduced in capital city of Jakarta under Governor Ali Sadikin proposal. From 1980 to 2010, without FPP, it was predicted that Indonesia would be populated by 340 Million. In fact, The census survey conducted in 2010 showed that the country was inhabited by 236.7 Million, minus 3.7 Million from the initial target of 233 Million. It is an enormous number, but the program eventually success to halt 100 million births. ${ }^{11}$

\section{THE CONTRA'S PERSPECTIVE}

In general, based on data from the BKKBN, Indonesia's Population Growth Rate (PGR) is relatively high. Until the end of 2018, Indonesia's PGR was $1.39 \%$ per year, which means that every year, there are 4.2 million to nearly 4.8 million newborns in Indonesia. This figure has been down from 2010 by $1.49 \%$, although the decline is sluggish. On the other hand, Data from the Department of Population and Civil Registration (Disdukcapil) of Bali Province revealed the number of Balinese people has stagnated, especially since $2015 .^{5}$

By contrast, in the previous Governor's period, Made mangku Pastika said that it was the FPP that has been stagnated in the last few years which then affected the rate of growth of the population of Bali, which averaged 2.15 per cent above the national average. This development has made the inhabitant reached more than 4.2 million people and heavily burdened the island of Bali. ${ }^{13}$

In addition, UGM Population Expert, Dr $\mathrm{Ni}$ Wayan Suriastini revealed similar statement that Bali is experiencing demographic changes. Bali's fast-growing tourism sector has had a positive impact on economic growth in Bali; subsequently attracted urbanisation as its side effect. She suggested that based on the data of the Central Statistics Agency (BPS), there are more than double in population increases from 1961 to 2019. The population density in Bali grew from the initial capacity of 400 people per kilometre to 750 people per kilometre. With additional changes in the composition of the population related to origin, ethnicity, social status, and religion due to migration factors. Excessive capacity also results in land conversion into housing, as well as ecological crises in the availability of clean water and waste management issues. ${ }^{15}$ 


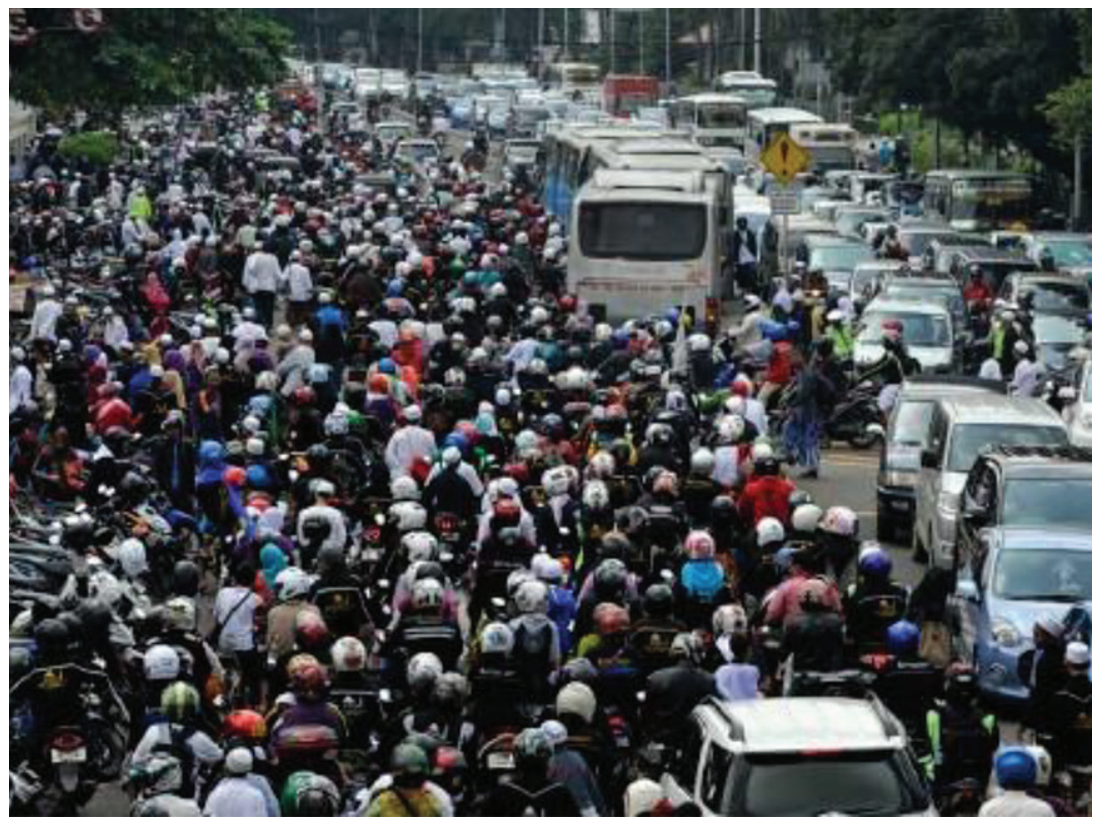

Figure 5. The population density in Bali grew from the initial capacity of 400 people per kilometre to 750 people per kilometre. ${ }^{14}$

\section{CONCLUSION}

The central government deployed FPP as an effective way to prevent population explosion in the last fifty years; which is highly crucial to ensure the society's welfare in future. In contrast, apparently, from the Governor of Bali, Wayan Koster's perspective, the program is subduing Balinese society growth, and threatening the survivability of the third and fourth child generations. Through the governor Instruction number 1545 of 2019 concerning the Socialization of the KBFP Planning Program, it is expected the Balinese family would decide to have more than two children, as the Governor's wish to protect the ancestral noble heritage.

In these times, there are several things that a family should be taken into account before deciding to follow KBFP program; from the female side agreement, family's cashflow condition, and recent demographic situation of Bali that has been expanding rapidly for years. Nevertheless, the instruction is not sternly applied, since there is no sanction for the society who wish not to follow the government's suggestion. As a verdict, a Balinese family still own the power to decide independently what they may find suitable for their future.

\section{REFERENCES:}

1. N Hikmah. Pertahankan Budaya Bali, Koster Ingin Modifikasi KB. News[dot]okezone. 2018. Available at URL: https://news.okezone.com/read/2018/03/15/340/1872938/ pertahankan-budaya-bali-koster-ingin-modifikasi-kb
2. WS Dinata. Era Baru Bali Ala Koster, Ini Sederet Program Dan Rencana Besarnya. tribun-bali[dot]com. 2018. Available at URL: https://bali.tribunnews.com/2018/08/02/ era-baru-bali-ala-koster-ini-sederet-program-danrencana-besarnya?page =all.

3. Image retrieved from Bali Post 'KELUARKAN INSTRUKSI KB KRAMA BALI, BEGINI ALASAN GUBERNUR KOSTER'. Bali post. 2019. Available at URL: http:// www.balipost.com/news/2019/06/29/79565/KeluarkanInstruksi-KB-Krama-Bali,...html

4. Anonymous. Generasi Adat Bali Terancam Hilang karena KB. Era[dot]id. 2018. Available at URL: https://www.era. $\mathrm{id} / \mathrm{read} / \mathrm{bWUqkG}$-generasi-adat-bali-terancam-hilangkarena-kb

5. Anonymous. Program KB dengan 4 Anak Ala Pemprov Bali, Seperti Apa?. Kumparan. 2019. Available at URL: https:// kumparan.com/@kumparanmom/program-kb-dengan-4anak-ala-pemprov-bali-seperti-apa-1rOxMnbBnAi

6. Image retrieved from foto indonesia jaman dulu 'Empat anak Bali dalam pakaian adat, sekitar 1920'. Pinterest. 2019. Available at URL: https://www.pinterest.com/ pin/649081365022699356/

7. Hari Ini Koster-Ace Resmi Pimpin Bali. Nusa bali. 2018. Available at URL: https://www.nusabali.com/berita/37191/ hari-ini-koster-ace-resmi-pimpin-bali

8. A Mardiastuti. Setop KB, Koster Tegaskan Hak Warga Bali Punya Wayan-Made-Nyoman-Ketut. News[dot] detik. 2019. Available at URL: https://news.detik.com/ berita/d-4603103/setop-kb-koster-tegaskan-hak-wargabali-punya-wayan-made-nyoman-ketut

9. Image retrieved from Cegah Ledakan Penduduk, Program KB Digencarkan. RRI. 2017. Available at URL: http:// rri.co.id/post/berita/357276/nasional/cegah_ledakan_ penduduk_program_kb_digencarkan.html

10. P Matanasi. Sejarah KB dan Ide Dua Anak Cukup dari Era Sukarno sampai Soeharto. Tirto[dot]id. 2019. Available at URL: https://tirto.id/sejarah-kb-dan-ide-dua-anak-cukupdari-era-sukarno-sampai-soeharto-ecJj

11. Daniel P. KB 2 Anak Cukup Agar Leluasa Rencanakan Masa Depan Keluarga. Medan inside. 2019. Available at URL: https://medaninside.com/kb-2-anak-cukup-agarleluasa-rencanakan-masa-depan-keluarga/

12. Image retrieved from slide by BKKBN Provinsi Bali 'KEBIJAKAN DAN STRATEGI PEMBANGUNAN KEPENDUDUKAN DAN KB TAHUN 2012' presented on Pasca Rakerda Pembangunan KKB Provinsi Bali Denpasar, 9 Maret 2012. Available at URL: https:// slideplayer.info/slide/11892729/

13. Anonymous. Jumlah Penduduk Sudah 4,2 Juta, Aduh Ini Berat bagi Bali. tribun-bali[dot].com. 2018. Available at URL: https://bali.tribunnews.com/2018/04/18/jumlahpenduduk-sudah-42-juta-aduh-ini-berat-bagi-bali.

14. Image retrieved from Facts of Indonesia '12 Reasons Why Indonesia is Over Populated. 2019. Available at URL: https://factsofindonesia.com/why-indonesia-is-overpopulated

15. WS Dinata. Pertumbuhan Penduduk Dua Kali Lipat, Pakar Kependudukan UGM Sebut Ada yang 'Hilang' di Bali. tribun-bali[dot].com. 2019. Available at URL: https://bali. tribunnews.com/2019/05/25/pertumbuhan-pendudukdua-kali-lipat-pakar-kependudukan-ugm-sebut-adayang-hilang-di-bali.

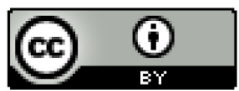

This work is licensed under a Creative Commons Attribution 